\title{
Benthic fluxes of dissolved organic nitrogen in the lower St. Lawrence estuary and implications for selective organic matter degradation
}

\author{
M. Alkhatib ${ }^{1,2}$, P. A. del Giorgio ${ }^{2}$, Y. Gelinas ${ }^{3}$, and M. F. Lehmann ${ }^{4}$ \\ ${ }^{1}$ Geochemistry and Geodynamics Research Center, GEOTOP, CP 8888, succ. Centre-Ville, Montreal, \\ Quebec, H3C 3P8, Canada \\ ${ }^{2}$ Department of Biology, University of Quebec at Montreal (UQAM), CP 8888, Succ. Centre-Ville, Montreal, Quebec, H3C \\ 3P8, Canada \\ ${ }^{3}$ GEOTOP and Department of Chemistry and Biochemistry, Concordia University, 7141 Sherbrooke St. W., Montreal, \\ Quebec, H4B 1R6, Canada \\ ${ }^{4}$ Department for Environmental Sciences, Bernoullistrasse 30, University of Basel, 4056 Basel, Switzerland
}

Correspondence to: M. F. Lehmann (moritz.lehmann@unibas.ch)

Received: 25 April 2013 - Published in Biogeosciences Discuss.: 13 May 2013

Revised: 13 September 2013 - Accepted: 14 October 2013 - Published: 22 November 2013

\begin{abstract}
The distribution of dissolved organic nitrogen (DON) and carbon (DOC) in sediment porewaters was determined at nine locations along the St. Lawrence estuary and in the gulf of St. Lawrence. In a previous manuscript (Alkhatib et al., 2012a), we have shown that this study area is characterized by gradients in the sedimentary particulate organic matter (POM) reactivity, bottom water oxygen concentrations, and benthic respiration rates. Based on the porewater profiles, we estimated the benthic diffusive fluxes of DON and DOC in the same area. Our results show that DON fluxed out of the sediments at significant rates (110 to $430 \mu \mathrm{mol} \mathrm{m} \mathrm{m}^{-2} \mathrm{~d}^{-1}$ ). DON fluxes were positively correlated with sedimentary POM reactivity and varied inversely with sediment oxygen exposure time (OET), suggesting direct links between POM quality, aerobic remineralization and the release of DON to the water column. DON fluxes were on the order of 30 to $64 \%$ of the total benthic inorganic fixed $\mathrm{N}$ loss due to denitrification, and often exceeded the diffusive nitrate fluxes into the sediments. Hence they represented a large fraction of the total benthic $\mathrm{N}$ exchange, a result that is particularly important in light of the fact that DON fluxes are usually not accounted for in estuarine and coastal zone nutrient budgets. In contrast to DON, DOC fluxes out of the sediments did not show any significant spatial variation along the Laurentian Channel (LC) between the estuary
\end{abstract}

and the gulf $\left(2100 \pm 100 \mu \mathrm{mol} \mathrm{m} \mathrm{m}^{-2} \mathrm{~d}^{-1}\right)$. The molar $\mathrm{C} / \mathrm{N}$ ratio of dissolved organic matter (DOM) in porewater and the overlying bottom water varied significantly along the transect, with lowest $\mathrm{C} / \mathrm{N}$ in the lower estuary (5-6) and highest $\mathrm{C} / \mathrm{N}(>10)$ in the gulf. Large differences between the $\mathrm{C} / \mathrm{N}$ ratios of porewater DOM and POM are mainly attributed to a combination of selective POM hydrolysis and elemental fractionation during subsequent DOM mineralization, but selective adsorption of DOM to mineral phases could not be excluded as a potential $\mathrm{C} / \mathrm{N}$ fractionating process. The extent of this $\mathrm{C}$ - versus $\mathrm{N}$ - element partitioning seems to be linked to POM reactivity and redox conditions in the sediment porewaters. Our results thus highlight the variable effects selective organic matter (OM) preservation can have on bulk sedimentary $\mathrm{C} / \mathrm{N}$ ratios, decoupling the primary source $\mathrm{C} / \mathrm{N}$ signatures from those in sedimentary paleoenvironmental archives. Our study further underscores that the role of estuarine sediments as efficient sinks of bioavailable nitrogen is strongly influenced by the release of DON during early diagenetic reactions, and that DON fluxes from continental margin sediments represent an important internal source of $\mathrm{N}$ to the ocean. 


\section{Introduction}

Coastal marine systems are areas under particularly high environmental stress due to increased inputs of nutrients and organic matter (OM) from different land sources that strongly influence both water quality and the biota (Gilbert et al., 2005; Thibodeau et al., 2006). Marine and estuarine systems are biogeochemically responsive to fixed nitrogen $(\mathrm{N})$, exhibiting rapid uptake of dissolved inorganic $\mathrm{N}$ (DIN) and dissolved organic N (DON) (Seitzinger et al., 2002; Seitzinger and Sanders, 1999). In estuaries, however, DIN accounts for only a portion of the total $\mathrm{N}$ inputs, while DON is often a much more important (30-80\%) component of the dissolved N pool (Berman and Bronk, 2003; Lønborg et al., 2009). In marine sediments, a large portion of particulate organic matter (POM) is recycled by bacterial hydrolysis during early sedimentary diagenesis; this results in the accumulation of dissolved organic components (DOM) in the sediment porewater. Subsequently, several processes can affect the composition and size of the benthic DOM pool, namely the bacterially mediated remineralization of DOM to $\mathrm{CO}_{2}$ and nutrients, diffusion to the overlying bottom water (where it can ultimately be assimilated by phytoplankton and bacteria in the water column), and/or stabilization and burial in sediments due to abiotic adsorption on mineral surfaces and complexation by metal hydroxide nanoparticles and geopolymerization (Alperin et al., 1999; Burdige, 2001; Lalonde et al., 2012). DOC and DON dynamics in sediments and their release to the water column are important in the context of the productivity of these aquatic environments, and the exchange of climate relevant gases with the atmosphere.

DON has seldom been considered in $\mathrm{N}$ budgets of estuaries and the ocean, in part because it is generally assumed to be mostly recalcitrant (e.g. Berman and Bronk, 2003; Knapp et al., 2005; Bourbonnais et al., 2009). However, many algae and bacteria have the capacity to use some forms of DON as a source of $\mathrm{N}$ for biosynthesis (Seitzinger et al., 2002; Seitzinger and Sanders, 1999). Therefore, N budgets for aquatic ecosystems based only on DIN sources and sinks may underestimate the pool of bioavailable $\mathrm{N}$ (Seitzinger et al., 2002). Likewise, most benthic studies have mainly focused on net DIN fluxes when assessing total denitrification rates and the $\mathrm{N}$ elimination capacity of the estuarine sediments, neglecting the reflux of $\mathrm{N}$ as DON from particulate OM hydrolysis/lysis. For example, Thibodeau et al. (2010) have shown that sediments of the Laurentian Channel (LC) function as an efficient sink for nitrate, especially in the lower St. Lawrence estuary section, but the role of sediments as a potential source of DON and the biogeochemical role of benthic DON fluxes have not been investigated yet.

Another aspect that has not been well explored to date is the connection between DON and DOC dynamics in estuarine sediments, which can provide insight into element fractionation during benthic remineralization of sedimentary POM. The differential susceptibility of dissolved organic components with variable carbon-to-nitrogen $(\mathrm{C} / \mathrm{N})$ ratios to microbial degradation within the sediments, and its role with regards to ecosystem respiration and the generation of basin-scale oxygen deficits (e.g. hypoxia) has been a matter of unresolved debate (Faganeli et al., 1991; Lahajnar et al., 2005; Lønborg et al., 2009). Therefore, the identification of key reaction and transport processes that affect porewater DOC and DON distributions is critical to assessing the significance of benthic metabolism during early sedimentary diagenesis and the associated alteration of the bulk sedimentary organic matter pool.

It is generally accepted that refractory POM in sediments has a higher $\mathrm{C} / \mathrm{N}$ atomic ratio and is more resistant to further alteration by bacterial degradation than more bioavailable POM in the water column (Meyers and Eadie, 1993; Bourgoin and Tremblay, 2010). Hence it is reasonable to assume that general sediment characteristics (i.e., amount, composition and reactivity/age of the POM) and redox conditions in estuarine and coastal-area sediments may influence not only the overall rates of benthic inorganic and organic solute exchange (Alkhatib et al., 2012a; Thibodeau et al., 2010), but also the element partitioning during remineralization. However, the effect of POM reactivity on the fluxes and fate of remineralized DOM remains uncertain.

Here we provide a detailed assessment of the distribution of DON and DOC in sediments and in near-bottom waters along a transect from the St. Lawrence River estuary to the gulf of St. Lawrence, which is characterized by systematic changes in sediment OM reactivity and bottom water oxygenation (Lehmann et al., 2009; Alkhatib et al., 2012a, b). We first tested the suitability of different porewater extraction techniques for DOM. We then used the porewater DON and DOC profiles to estimate benthic diffusive fluxes of DON and DOC in the estuary and in the gulf. The main goals of this study were (1) to investigate the spatial heterogeneity in DON and DOC fluxes in the St. Lawrence estuary, (2) to establish the connection between the DON and DOC fluxes, as well as the reactivity of the sedimentary POM between these fluxes, particularly in terms of potential elemental discrimination during hydrolysis and bacterial degradation, and (3) to assess the potential contribution of benthic DON fluxes to the net dissolved $\mathrm{N}$ exchange rates at the sediment-water interface (SWI) along the estuary.

\section{Materials and methods}

\subsection{Study area}

The bathymetry of the St. Lawrence River estuary is dominated by the Laurentian Channel (LC), a $250-500 \mathrm{~m}$ deep submarine valley that extends landward $1240 \mathrm{~km}$ from the edge of the Atlantic continental shelf (Fig. 1). The gulf of St. Lawrence, a large $\left(250000 \mathrm{~km}^{2}\right)$ and roughly triangular inland sea, is connected to the Atlantic by the Strait of Belle 


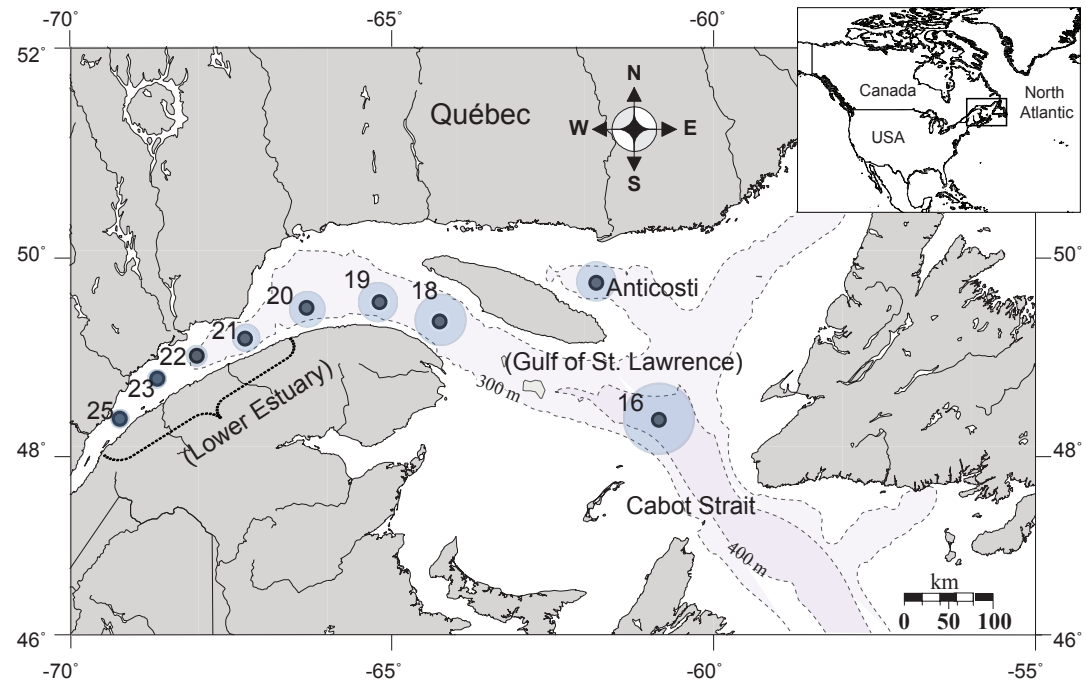

Fig. 1. Sampling locations in the St. Lawrence estuary and gulf. Bathymetric contours outline the Laurentian Channel along the 300 and $400 \mathrm{~m}$ isobaths. The size of shadowed circles around study sites denotes the relative dissolved $\mathrm{O}_{2}$ concentrations (see Table 1 for absolute values).

Isle and Cabot Strait at the northeast and southeast corners, respectively. Water mass movement in the St. Lawrence system is characterized by an estuarine circulation: less saline water flows seaward in the surface mixed layer, overlying the more saline water mass that forms in the northwest Atlantic and flows landward. The water in the deeper layer is isolated from the atmosphere by a permanent pycnocline at $100-150 \mathrm{~m}$ depth, and the water residence time is approximately 3-4 yr (Gilbert et al., 2005). As the deep-water mass flows landward, it gradually loses oxygen (primarily through aerobic microbial respiration). Sedimentary respiration was plausibly pointed out as the most important sink of oxygen in the St. Lawrence estuarine system (Lehmann et al., 2009), and yet the relative importance of benthic versus pelagic oxygen demand in the St. Lawrence estuary is an ongoing debate (Bourgault et al., 2012). In previous work, we have shown that POM source, oxygen concentration, benthic nutrient and DO fluxes, and POM reactivity vary along the Laurentian Channel (Alkhatib et al., 2012a; Thibodeau et al., 2010). Chlorin- and amino acid-based degradation indices show that sedimentary $\mathrm{OM}$ in the lower estuary is more reactive than in the gulf (Alkhatib et al., 2012a; see Table 1). Carbon isotope measurements and $\mathrm{C} / \mathrm{N}$ ratios indicate that sedimentary POM along the lower estuary and the gulf is mainly of marine origin. The terrestrial content of the sedimentary $\mathrm{OM}$ pool decreases with distance from the head of the lower estuary, as does sediment reactivity (Louchouarn et al., 1997; Alkhatib et al., 2012a).

\subsection{Sampling}

Sediment multicores and box cores were recovered at eight stations along the LC (stations 16-25) and at one station at the head of the Anticosti Channel in the gulf during two cruises in June and August 2006 (Fig. 1). Stations were chosen to represent the spatial heterogeneity in sedimentary OM characteristics (see above), and hydro-chemical parameters (e.g. dissolved oxygen (DO), salinity) in the overlying water. Sediment porewaters were extracted immediately after core recovery using the whole-core squeezing (WCS) method (Jahnke, 1988; Bender et al., 1987). During porewater extraction, the multicores were kept at in situ temperatures by wrapping the core tubes with ice bags. Extracting porewater from the upper 1.5 to $2 \mathrm{~cm}$ generally took about 20-30 min. The WCS is a porewater-sampling technique that yields millimeter depth resolution near the sediment-water interface. Water samples were collected with syringes equipped with Teflon coated pistons. For collecting porewater from greater depths than allowed by WCS, but also as a quality control of WCS data and for sampling method comparison, porewater was extracted using Rhizon membrane samplers (SeebergElverfeldt et al., 2005). The sediments processed with the Rhizon membrane samplers were obtained from box cores using push-core liners with holes $(0.5 \mathrm{~mm}$ diameter $)$ at $1 \mathrm{~cm}$ intervals. DON blank contribution of the Rhizon sampler was negligible. Using the Rhizon sampling technique, porewater can be sampled with minimum disturbance to the sediment structure, whereas the WCS method applies high pressures to the sediments, which can lead to rupturing of benthic organisms and the lysis of bacterial or algal cells.

Water samples collected for DIN and total dissolved $\mathrm{N}$ (TDN, the sum of $\mathrm{NO}_{3}^{-}, \mathrm{NO}_{2}^{-}, \mathrm{NH}_{4}^{+}$and $\mathrm{DON}$ ) analyses were filtered through $0.45 \mu \mathrm{m}$ Teflon syringe filters. For DOC water samples, PTFE syringe filters were used. DIN samples were stored frozen in pre-washed plastic vials until analysis 
Table 1. Biogeochemical parameters of sediments in the estuary and gulf of St. Lawrence.

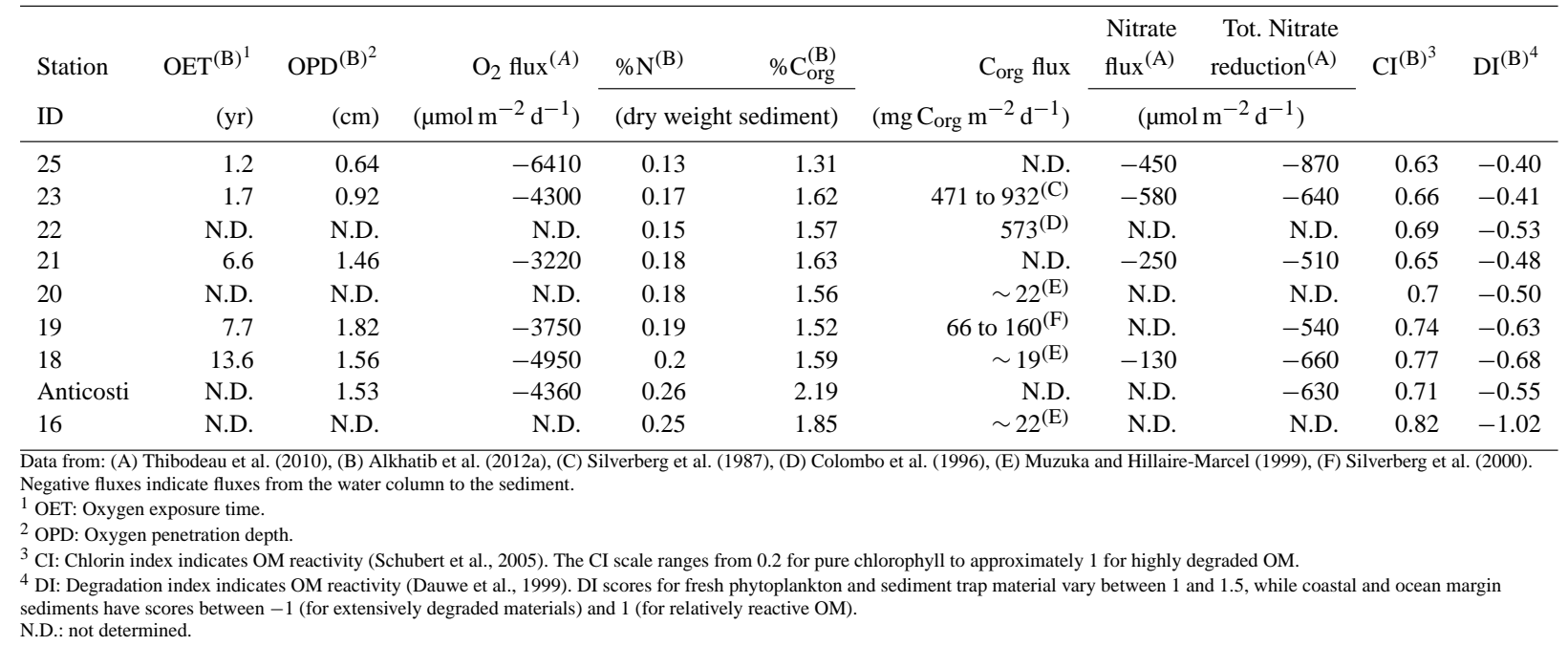

in the lab. Pore water samples for DOC analyses were kept acidified with hydrogen chloride $(\mathrm{HCl})(\mathrm{pH}<2)$ in glass vials (combusted, $500^{\circ} \mathrm{C}, 3 \mathrm{~h}$ ) and stored in the dark prior to analysis.

\subsection{Laboratory analyses}

The concentration of TDN for water samples was measured using the persulfate oxidation method following Solorzano and Sharp (1980). Persulfate was recrystallized three times prior to oxidation to reduce the $\mathrm{N}$ blank (Bronk et al., 2000). For TDN determination, $0.5 \mathrm{~mL}$ of alkaline persulfate oxidizing reagent was added to $3 \mathrm{~mL}$ of sample in a borosilicate glass test tube. Samples and three test tubes with the persulfate oxidation reagent only (blank) were then autoclaved for $45 \mathrm{~min}$ to quantitatively convert TDN to $\mathrm{NO}_{3}^{-}$. TDNderived nitrate was then quantified using an Antek $7020 \mathrm{Ni}$ tric Oxide Analyzer, where nitrate was reduced to nitric oxide (NO) in an acidic heated $\left(90^{\circ} \mathrm{C}\right)$ vanadium (III) solution (Braman and Hendrix, 1989), and the NO was measured by chemiluminescence detection. Reproducibility for replicate TDN analyses was better than $3 \%$ or $\pm 0.5 \mu \mathrm{mol} \mathrm{L}^{-1}$. The total procedural blank never exceeded $3 \mu \mathrm{mol} \mathrm{L}^{-1}$, and was on average $2 \mu \mathrm{mol} \mathrm{L}^{-1}$. TDN concentrations were corrected for blank contribution. Sample nitrate + nitrite concentrations were also measured using the vanadium method, with a reproducibility of \pm 0.2 . DON was determined by subtracting total dissolved inorganic nitrogen (DIN; nitrate, nitrite, and ammonia) from TDN, where $\mathrm{NH}_{4}^{+}$concentrations were measured using standard colorimetric autoanalysis (Hansen and Koroleff, 1999), with a standard deviation for replicate $(n \geq 3)$ measurements of $\pm 0.25 \mu \mathrm{mol} \mathrm{L}^{-1}$. The propagated error for DON concentrations based on using standard deviations of the DIN and TDN measurements was $\pm 0.6 \mu \mathrm{mol} \mathrm{L}^{-1}$. DOC concentrations were measured by high-temperature catalytic oxidation (HTCO) using a Shimadzu TOC 5000 analyzer. The samples were filtered and acidified onboard directly after collection. Once in the laboratory, samples were purged with oxygen to remove inorganic carbon. A sample aliquot of $100 \mu \mathrm{L}$ was then injected into the combustion column packed with platinum-coated alumina beads held at $680^{\circ} \mathrm{C}$. Organic carbon compounds were combusted and quantitatively converted to $\mathrm{CO}_{2}$, which was quantified by a non-dispersive infrared detector.

\subsection{DOC and DON benthic fluxes}

DOM fluxes $(F)$ across the SWI were estimated based on porewater concentration gradients (WCS or Rhizon) using Fick's first law of diffusion (Berner, 1980; Boudreau, 1996):

$F=D_{\mathrm{sed}} \Delta C / \Delta z$,

where $D_{\text {sed }}$ is the temperature-dependent free diffusion coefficient for DOM $\left(D^{\circ}\right.$, in $\left.\mathrm{cm}^{2} \mathrm{~s}^{-1}\right)$, corrected for sediment porosity (Boudreau, 1996), and $\Delta \mathrm{C} / \Delta z$ is the solute (i.e., DON or DOC) concentration gradient with depth $\mathrm{z}$ in the sediment. $\Delta \mathrm{C} / \Delta z$ was calculated from the first derivative of best-fit curves of the WCS-derived DOC or DON concentration profiles just below the sediment-water interface. To calculate $F_{\mathrm{DON}}$ from Rhizon membrane profiles, $\Delta \mathrm{C} / \Delta z$ was calculated as the concentration difference between the overlying water and the first sample below the SWI, in all cases at depths of less than $2 \mathrm{~cm}$. A similar approach was used in previous work (Martin and McCorkle, 1993; Lahajnar et al., 2005; Hall et al., 2007). Bottom water temperatures ranged from 3 to $5{ }^{\circ} \mathrm{C}$, and the porosity of the surface sediments generally decreased from 95 to $75 \%$ within the top $5 \mathrm{~cm}$. To determine $D^{\circ}$ for DOC and DON in seawater, we used the empirical relationship between molecular diffusion 
DON concentration $\left(\mu \mathrm{mol} \mathrm{L} \mathrm{L}^{-1}\right)$
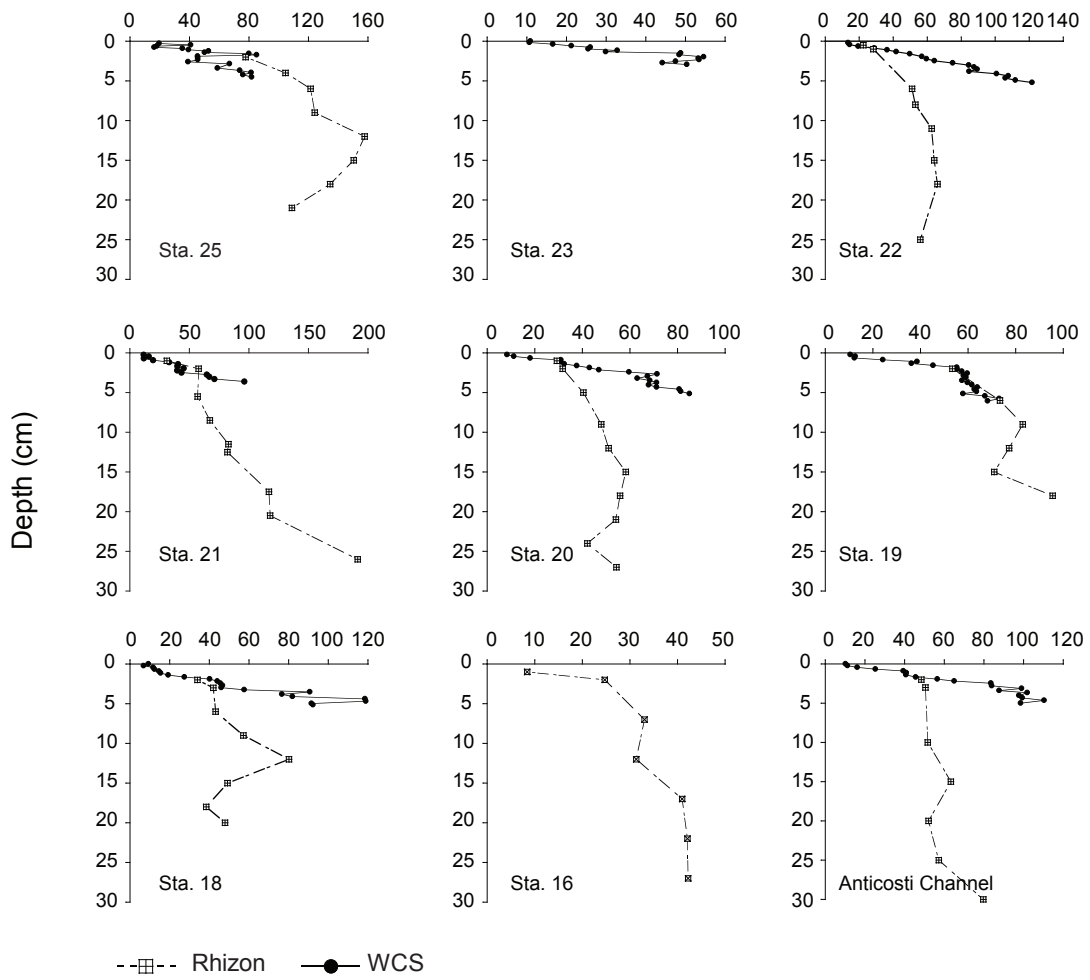

Fig. 2. Pore water profiles of dissolved organic nitrogen (DON) in the lower estuary and the gulf of St. Lawrence. Data for both whole-core squeezing (WCS) and the Rhizon membrane samples are shown.

and molecular weight (MW; at $25^{\circ} \mathrm{C}$ in distilled water) reported by Burdige et al. (1992), assuming a fixed average MW of 2500 daltons for both DON and DOC. This MW represents an intermediate value of previous estimates for porewater DOM. Alperin et al. (1999) proposed an average MW of 5000 daltons, while other studies show that the vast majority $(>80 \%)$ of the DOC and DON in sediment porewaters has a molecular weight of less than 3000 daltons. Uncertainty in the molecular weight has relatively little impact on the calculated fluxes because of the inverse cube-root relationship between $D^{\circ}$ and MW (Burdige et al., 1992). In situ salinity and temperature were taken into consideration using the Stokes-Einstein formula (Boudreau, 1996) and the corrected value for $D^{\circ}$ was $1.56 \times 10^{-6} \mathrm{~cm}^{2} \mathrm{~s}^{-1}$, translating into a $D_{\text {sed }}$ value of $1.5 \times 10^{-6} \mathrm{~cm}^{2} \mathrm{~s}^{-1}$ after correction for sediment porosity.

\section{Results}

\subsection{DON and DOC in sediment porewaters}

Sediment profiles of DON and DOC are shown in Figs. 2 and 3, respectively. In most cores, the porewater DON concentrations sharply increased below the SWI and reached a plateau of $40-200 \mu \mathrm{M}$ at a depth of about $5 \mathrm{~cm}$. At all sites, average porewater DON concentrations in the uppermost $\mathrm{cm}$ of the sediment column were at least twofold higher than in the overlying water column, suggesting a substantial flux of DON out of the sediments (see below). The agreement between WCS and Rhizon-sampler-derived DON profiles was good in the upper $1-2 \mathrm{~cm}$, but there were large differences between the two methods below that depth at several stations. In these deeper samples, WCS-derived DON concentrations were often manyfold higher (Fig. 2), suggesting artifacts that probably result from the pressure applied during the core squeezing (see discussion), which may lead to the release of intracellular DON. In general, average porewater DON concentrations in the uppermost centimeter of the sediment decreased eastward along the LC (Fig. 4a), with the highest subsurface DON concentrations measured landward at the lower estuary stations and the Anticosti Channel $(\sim 21 \mu \mathrm{M})$, and the lowest ones in the gulf $(8-18 \mu \mathrm{M})$.

Porewater DOC concentration profiles suggest a distribution qualitatively similar to that of DON. DOC concentrations in the uppermost centimeter of the sediment column did not show a clear spatial trend along the lower estuary (Fig. 4a), with average concentrations ranging between 97 and $141 \mu \mathrm{M}$. The highest DOC concentration was 
DOC concentration $\left(\mu \mathrm{mol} \mathrm{L} \mathrm{L}^{-1}\right)$

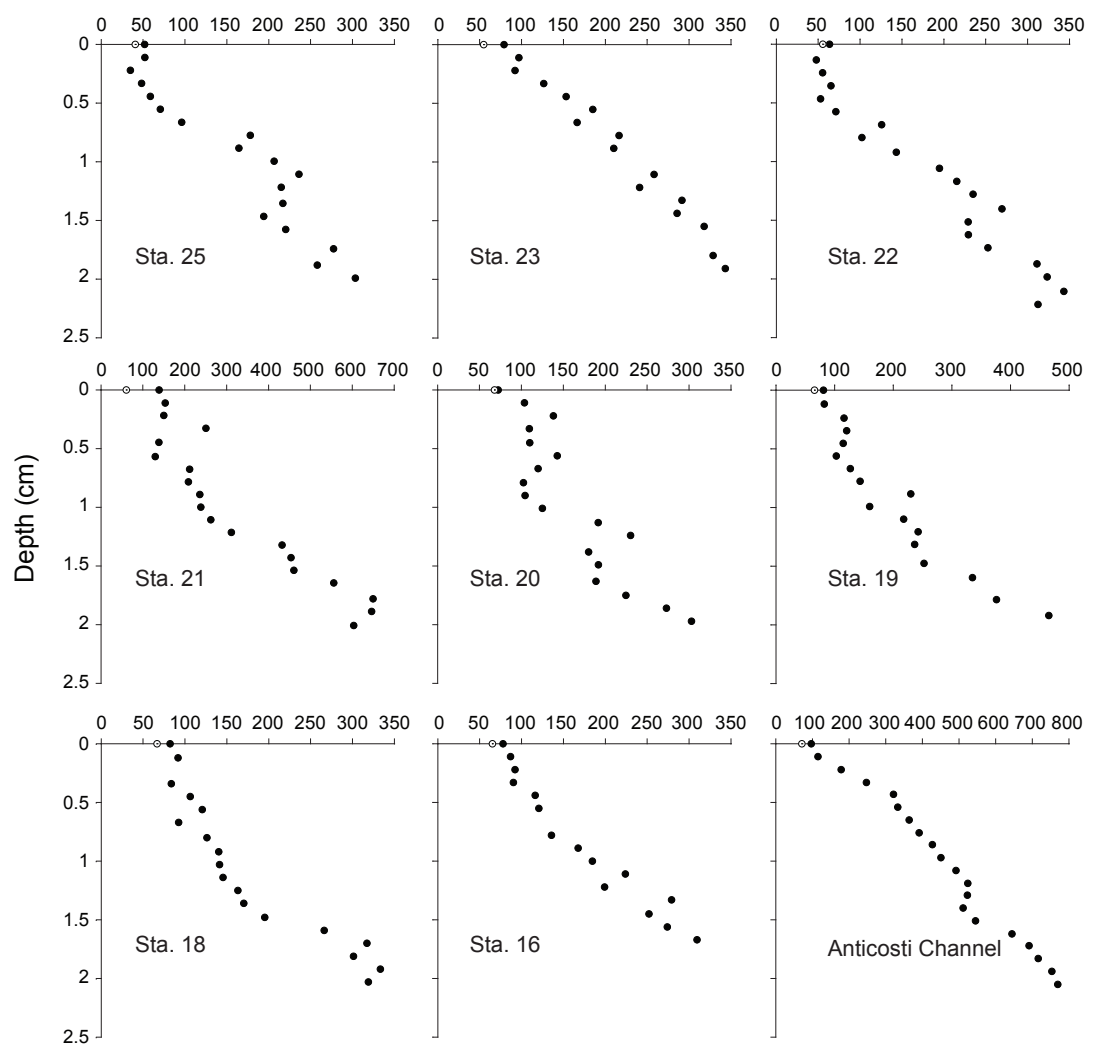

Fig. 3. Pore water profiles of dissolved organic carbon (DOC) in the lower estuary and the gulf of St. Lawrence. Open circles on the upper $x$ axes represent bottom-water DOC concentrations. Data from whole-core squeezing (WCS) samples.

measured in sediment porewater at the Anticosti Channel station $(\sim 274 \mu \mathrm{M})$. The porewater molar ratio of DOC-to-DON $\left(\mathrm{C} / \mathrm{N}_{\mathrm{DOM}}\right)$ in the uppermost centimeter in the sediment column varied between 5.2 at station 25 in the lower estuary and 11 at station 16, with a maximum of 13.3 at the Anticosti Channel station (Fig. 5).

\subsection{Benthic DON and DOC fluxes}

Benthic diffusive DON fluxes at the SWI based on Rhizon sample measurements were in general agreement with those determined using the WCS concentration gradients. Rhizonbased DON fluxes were slightly lower than the WCS-based ones only at station 18 and station 20 in the gulf (Table 2). Given the generally good agreement between of the two methods, we calculated, and used, the average DON flux. The highest DON fluxes (average of both WCS- and Rhizonbased calculations) were observed at the head of the LC ( $\sim 440 \mu \mathrm{mol} \mathrm{m} \mathrm{m}^{-2} \mathrm{~d}^{-1}$ at station 25 ) with fluxes decreasing seaward, and the lowest flux $\left(\sim 110 \mu \mathrm{mol} \mathrm{m}{ }^{-2} \mathrm{~d}^{-1}\right)$ measured at station 16. Diffusive DOC fluxes ( 0 to $\sim 2 \mathrm{~cm}$ depth profiles; WCS-based only) averaged $\sim 2100 \mu \mathrm{mol} \mathrm{m}^{-2} \mathrm{~d}^{-1}$ and did not display any consistent trend along the lower es- tuary seaward up to station 19 in the gulf; however, much lower DOC fluxes $\left(\sim 1400\right.$ and $\left.\sim 1300 \mu \mathrm{mol} \mathrm{m}^{-2} \mathrm{~d}^{-1}\right)$ were observed at station 18 and at station 16 , respectively (Table 2). The highest DOC flux $\left(\sim 3850 \mu \mathrm{mol} \mathrm{m} \mathrm{m}^{-2} \mathrm{~d}^{-1}\right)$ was observed at the Anticosti station (Table 2), consistent with the high porewater DOC and DON concentrations. The $\mathrm{C} / \mathrm{N}$ ratio of the DOM efflux from the sediments was lowest in the lower estuary (average $\mathrm{C} / \mathrm{N}$ of $\sim 5$ ), intermediate between station 22 and station 20 (average $\mathrm{C} / \mathrm{N}$ of $\sim 7$ ), and it was highest at station 16 and Anticosti in the gulf (average $\mathrm{C} / \mathrm{N}$ of 13) (Fig. 5).

\subsection{DON and DOC in the bottom water}

The DON concentrations in the bottom waters overlying the sediments were highest at the head of the LC at stations 25 and $23(\sim 10 \mu \mathrm{M})$ and were comparatively low in the gulf of St. Lawrence, with lowest concentrations at station 20 $(6.3 \mu \mathrm{M})$ (Fig. 4b). This pattern agrees well with the spatial trends in DON fluxes that we described above. By contrast, DOC concentrations were slightly higher in the gulf $(\sim 60 \mu \mathrm{M})$ than in the lower estuary $(\sim 50 \mu \mathrm{M})$. The highest DOC concentration was observed at the Anticosti station 
Table 2. DOC and DON fluxes at several locations along the Laurentian and Anticosti channels. DON flux was calculated from both WCS and Rhizon membrane porewater samples. The average DON flux is used for the calculation of flux ratios, as well as for the $\%$ DON flux calculation relative to nitrate fluxes and the total denitrification rates (from Thibodeau et al., 2010). All fluxes were positive, i.e., directed from the sediment to the water column.

\begin{tabular}{|c|c|c|c|c|c|c|}
\hline \multirow[t]{2}{*}{ Sta. ID } & $\begin{array}{l}\text { DOC flux } \\
\text { (WCS) }\end{array}$ & $\begin{array}{c}\text { DON flux } \\
\text { (Rhizon) }\end{array}$ & $\begin{array}{l}\text { DON flux } \\
\text { (WCS) }\end{array}$ & Av. DON flux & \multirow{2}{*}{$\begin{array}{l}\mathrm{DON} \text { flux / } \\
\mathrm{NO}_{3}^{-} \text {flux }\end{array}$} & \multirow{2}{*}{$\begin{array}{l}\text { DON flux/ Tot. } \\
\text { Nitrate reduction }\end{array}$} \\
\hline & \multicolumn{4}{|c|}{$\left(\mu \mathrm{mol} \mathrm{m}{ }^{-2} \mathrm{~d}^{-1}\right)$} & & \\
\hline Sta. 25 & 2150 & 440 & 420 & 430 & 0.95 & 0.49 \\
\hline Sta. 23 & 2120 & N.D. & 350 & 350 & 0.60 & 0.55 \\
\hline Sta. 22 & 2230 & 260 & 340 & 300 & N.D. & N.D. \\
\hline Sta. 21 & 2270 & 320 & 330 & 330 & 1.30 & 0.64 \\
\hline Sta. 20 & 1950 & 160 & 260 & 210 & N.D. & N.D. \\
\hline Sta. 19 & 2080 & 300 & 260 & 280 & N.D. & 0.52 \\
\hline Sta. 18 & 1430 & 170 & 230 & 200 & 1.54 & 0.30 \\
\hline Sta. 16 & 1310 & 110 & N.A. & 110 & N.D. & N.D. \\
\hline Anticosti & 3850 & 260 & 290 & 270 & N.D. & 0.43 \\
\hline
\end{tabular}
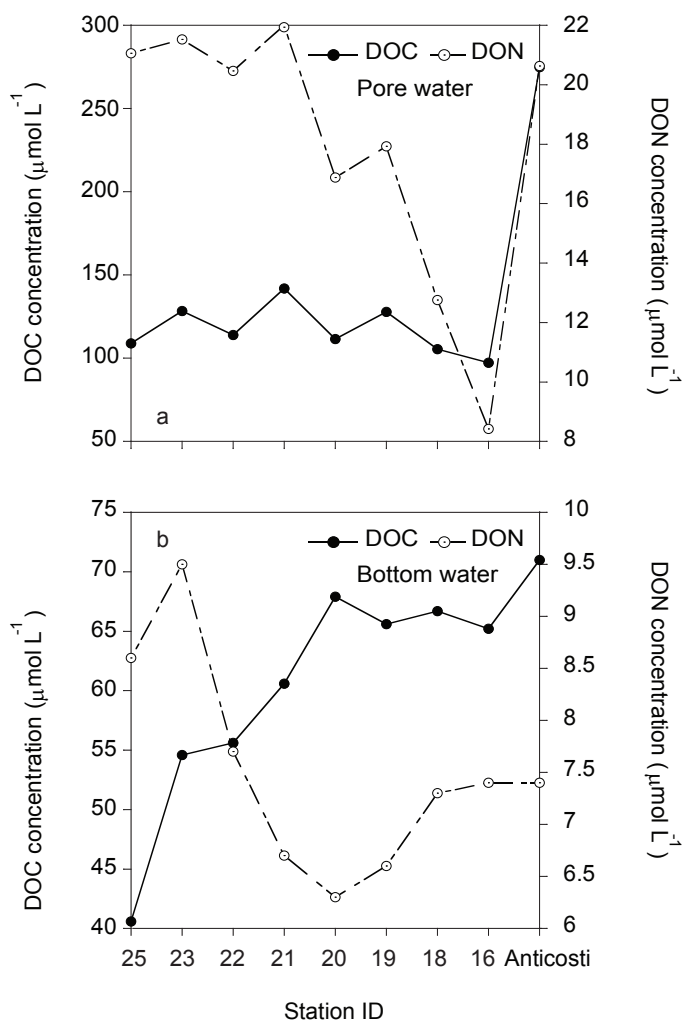

Fig. 4. Dissolved organic carbon (DOC, left axis) and dissolved organic nitrogen (DON, right axis) concentrations $\left(\mu \mathrm{mol} \mathrm{L}^{-1}\right)$ in: (a) pore waters (average of the first $\mathrm{cm}$ ), (b) overlying bottom water along the lower estuary and gulf of St. Lawrence.

$(82 \mu \mathrm{M})$. The observed patterns in bottom water DOC and DON concentrations resulted in a clear increasing trend in the bottom water DOM C / $\mathrm{N}$ ratios, from 5 in the lower estuary to $\sim 11$ at station 20 , and a decrease again to lower $\mathrm{C} / \mathrm{N}$ ratios $(\sim 9)$ towards station 16 in the gulf (Fig. 5).

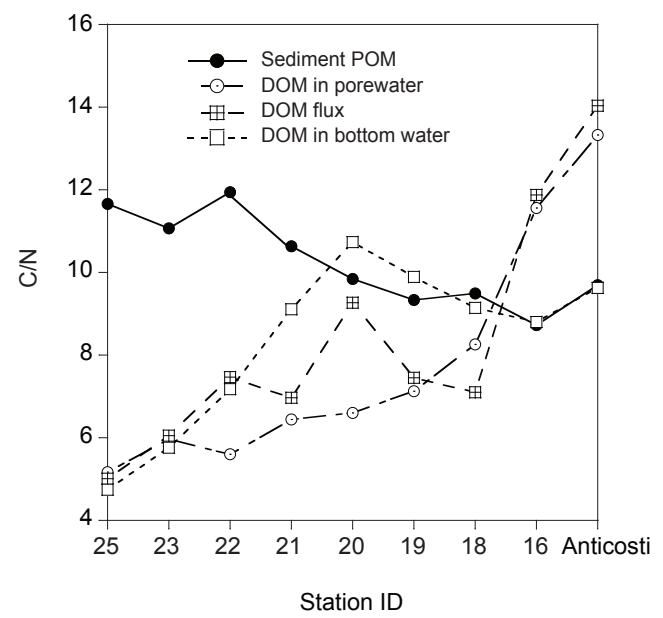

Fig. 5. Molar $\mathrm{C} / \mathrm{N}$ ratios in sedimentary particulate organic matter (POM), porewater dissolved organic matter, and sediments overlying bottom water along the lower estuary and gulf of St. Lawrence.

\section{Discussion}

\subsection{Suitability of whole-core squeezing for DOM extraction}

Previous studies on the applicability of WCS in determining DOC in sediment porewaters have shown that this porewater extraction technique tends to overestimate DOC concentrations in deeper layers of the sediments, most likely due to the lysis of bacterial cells (Bolliger et al., 1992; Martin and McCorkle, 1993). This bias is likely to increase with depth, as the pressure that has to be applied to the sediment core increases with the depth of the sediment layer from which porewater is extracted (Martin and McCorcle, 1993). Indeed, at several stations and at depths greater than $2-3 \mathrm{~cm}$, the average DON concentration measured by WCS was manyfold higher than that obtained for the Rhizon samples (Fig. 2). The observed differences were most probably 
due to the liberation of $\mathrm{N}$ stored in bacteria and other benthic micro-organisms (Benner, 2002; Tremblay and Benner, 2006) during the WCS processing, particularly at higher pressures (Bolliger et al., 1992; Martin and McCorkle, 1993). The agreement between WCS- and Rhizon-sampling-based [DON] in the upper $2 \mathrm{~cm}$ of the sediment column (see Fig. 2) suggests that such pressure effects, if present at all, are much less pronounced for the upper sediment layer below the SWI, and that (at least in the St. Lawrence sediments) WCS can be used to sample porewater for benthic flux determination.

Moreover, a large fraction of the total sedimentary organic matter is associated with mineral particles. Metal oxides that accumulate near the SWI at the oxic-anoxic interface can possibly act as DOM filters (Skoog et al., 1996; Arnarson and Keil, 2000; Skoog and Arias-Esquivel, 2009). As porewater is slowly forced through the interstices of the sediment during core squeezing, porewaters from deeper sediment layers come into contact with surface-reactive oxic sediments that were in equilibrium with waters with different DOM concentrations. DOM may equilibrate with the ambient mineral phase through adsorption/desorption reactions that occur on a sub-minute time scale (Alperin et al., 1999; Arnarson and Keil, 2000), and therefore, it is possible that DOC and DON concentration of WCS samples and the DOM composition is modified by solid-solution partitioning. Predicting, however, the combined effects of cell lysis and absorption/desorption of deep DOM diffusing through shallower sediment layers, and how these effects may change with depth is not straightforward. Even though the concentration of highly reactive nanophase ferrihydrite is highest near the SWI (van der Zee et al., 2003), the low pressure applied to the system during the extraction and short diffusion path may minimize these effects during extraction of porewater by WCS from the uppermost sediment layers.

\subsection{DOC and DON fluxes}

At all sites, DON and DOC concentrations were systematically higher in porewaters than in the water column bottom water (Fig. 4). The higher concentrations in porewaters imply a net production of DOM within the sediments, and a net upward flux of DON and DOC across the SWI. Numerous studies from a wide variety of marine environments have shown that DOC and DON concentrations in sediment porewater may be manyfold higher than in the overlying water (e.g. Martin and McCorkle, 1993; Blackburn et al., 1996; Burdige and Zheng, 1998; Alperin et al., 1999; Holcombe et al., 2001). We have summarized the published sedimentary fluxes of DON and DOC from different marine systems in Table 3. Our calculated sediment DON fluxes were much higher than, for example, reported fluxes from deep-sea sediments (Brunnegård et al., 2004), but generally within the range reported for other estuarine and continental shelf sites (review by Bronk and Steinberg, 2008; Table 3). DOC fluxes (1300 to $3900 \mu \mathrm{mol} \mathrm{m}^{-2} \mathrm{~d}^{-1}$ ) are within the range of values reported previously by Colombo et al. (1996) at two locations in the $\mathrm{LC}\left(\sim 1700 \mu \mathrm{mol} \mathrm{m}^{-2} \mathrm{~d}^{-1}\right)$, and similar to estimates from Chesapeake Bay sediments (1400 to $2900 \mu \mathrm{mol} \mathrm{m}^{-2} \mathrm{~d}^{-1}$ ) reported by Burdige and Homstead (1994).

We found the highest DON fluxes in sediments of the lower estuary and the lowest ones in the gulf (Table 2). We attribute these variations to patterns in POM reactivity across the sites as the fluxes strongly correlated with the chlorin in$\operatorname{dex}\left(\mathrm{CI}, r^{2}=0.83, n=9\right)$ and the degradation index (DI, $r^{2}=0.74, n=9$ ) (for definition CI and DI, see caption of Table 1; reactivity data from Alkhatib et al., 2012a) (Fig. 6a, b). In addition, there was an inverse correlation between DON fluxes and dissolved oxygen concentrations in the bottom waters $\left(r^{2}=0.83, n=9\right.$; Fig. 6c). Similarly, DON fluxes correlated negatively with the oxygen exposure time (OET), which defines the average time that sediment $\mathrm{OM}$ is exposed to "oxic" conditions during burial in the sediments (Hartnett et al., 1998; Hedges et al., 1999; $r^{2}=0.9, n=5$; Fig. 6d). The fact that higher DON fluxes were measured in the lower estuary than in the gulf would thus appear to be linked to an increased supply of more reactive POM, higher overall sediment POM reactivity, and, probably, to the lower DO concentration in the overlying bottom water (See Table 1; Bourgoin and Tremblay 2010; Alkhatib et al., 2012a).

A number of studies have shown a positive correlation between POM delivery to the sediment and DON concentration in porewaters (e.g. Hansen and Blackburn, 1991; Sloth et al., 1995). The rate-determining step for both aerobic and anaerobic microbial degradation of POM and production of DOM is the hydrolysis by extracellular enzymes (Wilczek et al., 2005). Higher POM reactivity induces the production and activity of bacterial hydrolytic enzymes (Boetius and Lochte, 1994; Wilczek et al., 2005), and hydrolysis proceeds under both oxic and anoxic conditions, although not necessarily always at the same rates (Hansen and Blackburn 1991; Kristensen and Holmer, 2001). In this regard, Thibodeau et al. (2010) recently reported that OM remineralization rates along the LC are highest in the lower estuary and decrease eastwards. Alkhatib et al. (2012a) also found a significant correlation between OM reactivity and the $\mathrm{OM}$ remineralization rates along the LC as reported by Thibodeau et al. $\left(2010 ; r^{2}=0.76, n=8\right)$. Therefore, it would appear that a high POM flux of relatively reactive $\mathrm{POM}$ is particularly conducive to high rates of OM hydrolysis in the lower estuary, resulting in both high porewater [DON] and high DON fluxes. Similarly, the inverse relationship between DON fluxes and dissolved $\mathrm{O}_{2}$ concentrations in the bottom waters, as well as OET, confirms the close links between redox conditions, sediment POM degradation, and DON production in the sediments. In an earlier paper (Alkhatib et al., 2012a), we argued that the sedimentary diagenesis and the degradation rate are largely controlled by the reactivity of available organic substrates, as opposed to the relative supply of different electron acceptors. 
Table 3. Comparison of calculated benthic DON and DOC fluxes along the Laurentian Channel and Anticosti Channel with benthic DON and DOC fluxes from other estuarine and coastal environments (non-exhaustive overview). All fluxes (in $\mu$ mol m${ }^{-2} \mathrm{~d}^{-1}$ ) are from the sediment to the water column.

\begin{tabular}{llll}
\hline Site & DON flux & DOC flux & Reference \\
\hline Laurentian Channel, Canada & $110-430$ & $1300-2150$ & This study \\
Anticosti Channel, Canada & 270 & 3850 & This study \\
Chesapeake Bay, USA, Site M3 & $60-320$ & $670-1650$ & Burdige and Zheng (1998) \\
Chesapeake Bay, USA, Site S3 & $40-550$ & $200-850$ & Burdige and Zheng (1998) \\
Laholmm Bay, Sweden & $100-400$ & - & Enoksson (1993) \\
Porcupine Abyssal Plain, NE Atlantic & 100 & - & Brunnegår et al. (2004) \\
Svalbard, Norway & 950 & - & Blackburn et al. (1996) \\
Temperate Australian Estuaries & - & up to 50000 & Maher and Eyre (2010) \\
Knebel Vig, Denmark & 3900 & - & Lomstein et al. (1998) \\
Mexican margin & - & $250-400$ & Holcombe et al. (2001) \\
California continental margin & - & $100-3100 \pm 2700$ & Burdige et al. (1999) \\
\hline
\end{tabular}
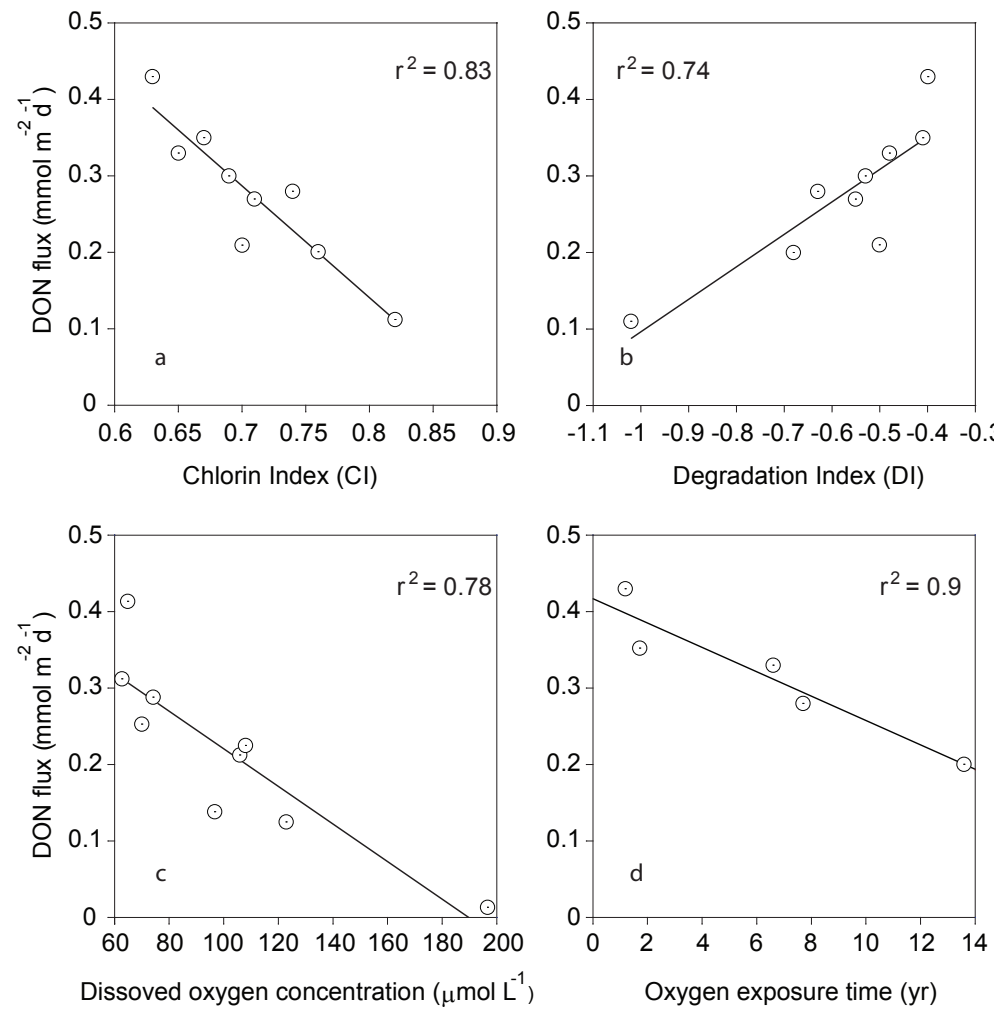

Fig. 6. Correlation between the dissolved organic nitrogen (DON) fluxes and reactivity indices: (a) the chlorin index (CI), (b) the degradation index (DI), as well as (c) dissolved oxygen, and (d) oxygen exposure time in sediments along the St. Lawrence estuary and the gulf of St. Lawrence. See caption of Table 1 for details on CI and DI.

In vitro laboratory experiments have shown much slower and less efficient anoxic degradation of refractory POM and carbon-rich substrates, such as complex lipids (Kristensen and Holmer, 2001; Emerson and Hedges, 2003). By contrast, remineralization rates of more reactive OM appear to be controlled by the quality and the quantity of available organic matter, and are also largely independent of sediment redox conditions (Burdige, 2007). The inverse correlations between dissolved $\mathrm{O}_{2}$ concentrations and OET with DON fluxes suggest that oxygen-sensitive POM (i.e., POM requiring oxic conditions for degradation) is selectively concentrated with increasing POM maturity seaward along the LC.

The minor variations in DOC fluxes that we observed over this wide range of environmental conditions, in terms of 
vertical OM flux, dissolved $\mathrm{O}_{2}$ concentration, and sediment POM reactivity, suggest a rather tight balance between production and consumption of labile DOC within the sediment, irrespective of the overall benthic activity in this system (Otto and Balzer, 1998). Because the bottom waters move inland along the LC, we would expect a continuous increase in DOC and DON concentrations owing to the cumulative flux of DOM across the SWI during transit. Figure $4 \mathrm{~b}$ shows that, as the bottom water currents move inland along the LC, DOC concentrations in the bottom water slightly decreased from $>60 \mu \mathrm{mol} \mathrm{L}^{-1}$ at station 20 to $<50 \mu \mathrm{mol} \mathrm{L}^{-1}$ at station 25 , while DON increased from $\sim 6 \mu \mathrm{mol} \mathrm{L}^{-1}$ to $\sim 10 \mu \mathrm{mol} \mathrm{L}^{-1}$ at the head of the LC (Fig. 5). The concentration gradients between the sediment and the bottom water DOC pools suggest a flux of DOC out of the sediments at all stations (Table 2) and an inland decline in bottom water DOC albeit the continuous DOC flux from the sediments is difficult to explain. It is possible that adsorption processes right at, and just below, the SWI can modulate benthic DOC exchange. More precisely, adsorption of DOM to mineral and metal oxides/hydroxides surfaces can potentially remove significant amounts of DOC from the porewater before it actually fluxes into the water column (Boto et al., 1989; Skoog et al., 1996; Arnarson and Keil, 2000; Skoog and Arias-Esquivel, 2009). Adsorption on mineral surfaces and coprecipitation with metal hydroxides are processes that take place at all depths in the sediment but that are more pronounced near the SWI, where the highly surface-reactive nanophase ferrihydrite is enriched (Lalonde et al., 2012). Our sampling resolution may not allow us to detect DOC adsorption right at the SWI. Obviously, such a "hidden" sink would certainly affect not only DOC, but also DON. Nevertheless, it is reasonable to assume that it could induce element partitioning due to the preferential adsorption/desorption of specific organic molecules with variable $\mathrm{C} / \mathrm{N}$ ratios (e.g. by the preferential adsorption of polysaccharides on reactive iron oxide phases). The parallel trends of the $\mathrm{C} / \mathrm{N}$ ratio in DOM in the porewater and in the bottom water (Fig. 5) seem to argue against such physicochemical constraints on element partitioning, and in the next section we will put our focus on $\mathrm{OM}$ remineralization as the main $\mathrm{C}$-versus- $\mathrm{N}$ partitioning mechanism. We need to keep in mind, however, that the respective sizes of the bottom water DOM pool and the sediment porewater pool are very different. There could be selective partitioning in the porewaters, with no discernable effect on the bottom water DOM, simply because the porewaters' contribution is too small.

\subsection{C versus N partitioning during DOM production and remineralization}

The differences in molar $\mathrm{C} / \mathrm{N}$ ratios between the porewater DOM and sedimentary POM along the estuarine transect suggest preferential hydrolysis of N-rich DOM during initial breakdown of sediment POM (except at station 16 and the
Anticosti station; see Fig. 5). Initial hydrolysis of freshly deposited POM in surface sediments generally produces DOM with a $\mathrm{C} / \mathrm{N}$ ratio that is lower than that of the deposited POM (Blackburn et al., 1996; Burdige and Zheng, 1998; Weston et al., 2006). We observed that the difference between $\mathrm{C} / \mathrm{N}$ ratios of sediment $\mathrm{POM}$ and porewater DOM $(\Delta \mathrm{C} / \mathrm{N}$ $\left.=\mathrm{C} / \mathrm{N}_{\mathrm{POM}}-\mathrm{C} / \mathrm{N}_{\mathrm{DOM}}\right)$ decreases along the $\mathrm{LC}$ from $\sim 6$ at the head of the $\mathrm{LC}$ to $\sim 1$ at station 18 , while the difference was negative (about -3 ) at station 16 and in the Anticosti Channel sediments (Fig. 5). There was a strong correlation between sediment POM reactivity and the $\Delta \mathrm{C} / \mathrm{N}\left(r^{2}=0.85\right.$, $n=8$, excluding the Channel Anticosti from the regression as its location is not on the estuarine transect line; Fig. 7a). The $\Delta \mathrm{C} / \mathrm{N}$ also correlated with the oxygen exposure time (OET) $\left(r^{2}=0.88, n=8\right.$; Fig. $\left.7 b\right)$. These patterns are most likely related to the nature of the hydrolysed sediment POM (i.e., hydrolysable (reactive) versus hydrolysis-resistant or oxygen-sensitive $\mathrm{OM}$ ), and to the mode of depolymerization, i.e., the initial hydrolysis step (or oxidative cleavage) of sedimentary POM to form dissolved intermediates, which is a function of the redox conditions in the sediments (Emerson and Hedges, 2003; Burdige, 2007). While the hydrolysis of more labile POM is not limited by oxygen availability and takes place at comparable rates under both oxic and anoxic redox conditions (Hansen and Blackburn, 1991; Emerson and Hedges, 1988, 2003), effective degradation of the hydrolysis-resistant refractory POM requires molecular oxygen (Emerson and Hedges, 1988). Most of the strong oxidants, such as peroxide $\left(\mathrm{H}_{2} \mathrm{O}_{2}\right)$ and other reactive oxygencontaining enzymes, are nonspecific, as they do not target specific compounds, chemical groups or types of bonds during the breakdown of more refractory POM (Fenchel et al., 1998; Emerson and Hedges, 1988); thus, they minimize element partitioning. Given that the CI and DI indexes reveal that sedimentary POM reactivity is highest in the lower estuary (stations 25, 23, 22, and 21) and becomes more refractory seaward along the LC, the fraction of hydrolysable POM likely decreases seaward, while that of hydrolysis-resistant POM increases.

Consistent with the observed increase in DOM C / $\mathrm{N}$ ratios (both in porewater and bottom water) seaward, we observed a decline in the $\mathrm{C} / \mathrm{N}$ ratio of the sedimentary POM pool (Fig. 5). While the extent to which immobilized DOM in bacterial biomass and DOM adsorbed to mineral particles (see last section) contributes to the $\mathrm{C} / \mathrm{N}$ signatures of the POM remains uncertain, it is clear that early diagenetic degradation of bulk OM, and the partitioning between the particulate and dissolved OM pools, is associated with an elemental fractionation of $\mathrm{C}$ versus $\mathrm{N}$, which appears to be sensitive to environmental conditions (i.e., bottom water $\mathrm{O}_{2}$ concentration) and sediment characteristics (i.e., OM reactivity). 

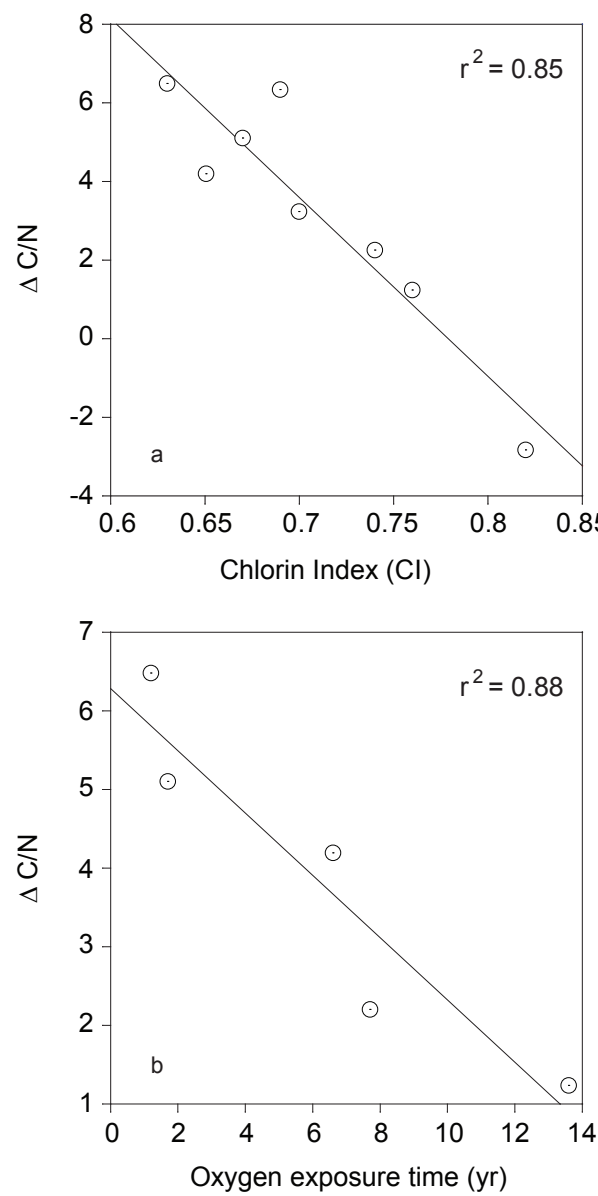

Fig. 7. Correlation between the differences between the molar $\mathrm{C} / \mathrm{N}$ ratios in sedimentary particulate organic matter (POM) and porewater dissolved organic matter $(\Delta \mathrm{C} / \mathrm{N})$ and (a) the chlorin index $(\mathrm{CI})$ and (b) oxygen exposure time in sediments along the St. Lawrence estuary and the gulf of St. Lawrence. See caption of Table 1 for details on CI

\subsection{Significance of benthic DON fluxes for estuarine $\mathbf{N}$ budgets}

In the lower estuary and the gulf, DON was the most important dissolved nitrogen component in porewater, comprising up to $85 \%$ of the TDN at the sedimentary redox transition zone. Thibodeau et al. (2010) reported that nitrate and ammonium fluxes out of the sediments are zero or very low at the same stations. To place the DON fluxes in the context of the total benthic nitrogen budget of the St. Lawrence system, we compared the $\mathrm{N}$ loss rates by sediment denitrification reported by Thibodeau et al. (2010), to the benthic DON fluxes estimated in this study. Observed DON fluxes account for 30 to $64 \%$ of the total benthic denitrification (including nitrification-denitrification coupling), as estimated by Thibodeau et al. (2010) from porewater nitrate gradients (Table 1). The extrapolation of the DON fluxes presented here (average $310 \mu \mathrm{mol} \mathrm{m}^{-2} \mathrm{~d}^{-1}$ ) to the total sed- iment surface area of the Laurentian Channel between stations 23 and $16\left(\sim 35700 \mathrm{~km}^{2}\right)$ suggests that between 40 and $60 \times 10^{6} \mathrm{~kg} \mathrm{~N} \mathrm{yr}^{-1}$ of DON are annually liberated from the sediments to the water column of the St. Lawrence estuary and gulf.

Given that DON fluxes that we present here are within the range of DON fluxes reported for various coastal marine environments (Bronk and Steinberg, 2008 and references therein), we assume that the DON fluxes from the St. Lawrence estuary and gulf sediments can be considered representative for other continental shelf regions. Assuming a global shelf area of $\sim 30 \times 10^{6} \mathrm{~km}^{2}$, (Milliman, 1993) and an average DON flux of $1.58 \times 10^{6} \mathrm{~g} \mathrm{~N} \mathrm{~km}^{-2} \mathrm{yr}^{-1}$ (equivalent to $310 \mu \mathrm{mol} \mathrm{m}^{-2} \mathrm{~d}^{-1}$ ), we calculate that the global benthic DON flux from shelf sediments may result in a flux of approximately $48 \mathrm{Tg} \mathrm{N} \mathrm{yr}^{-1}$. This estimate is $\sim 1.5$ times higher than the estimated riverine DON input to the ocean $\left(\sim 35 \mathrm{Tg} \mathrm{Nyr}^{-1}\right)$, and about one third to half of the total oceanic biological $\mathrm{N}_{2}$ fixation $\left(100-150 \mathrm{Tg} \mathrm{N} \mathrm{yr}^{-1}\right.$; Codispoti et al., 2001). We are aware of the fact that such extrapolations are problematic and that our estimates are associated with large uncertainty. Nevertheless, our study highlights that benthic DON fluxes are a key source of reduced $\mathrm{N}$ to the marine environment, representing an important component of the internal marine $\mathrm{N}$ cycle, at the ecosystem scale (e.g., the St. Lawrence system), and globally.

\section{Summary and concluding remarks}

In this study, we measured the DON and DOC concentrations of sediment porewater along the Laurentian Channel of the St. Lawrence estuary, and determined benthic DOC and DON fluxes in the lower estuary and the gulf of St. Lawrence. Our results suggest that both the sediment POM reactivity and the oxygen exposure time of organic particles after sedimentation influence the $\mathrm{C} / \mathrm{N}$ ratio of hydrolysed DOM. The degree of $\mathrm{C}$ versus $\mathrm{N}$ element partitioning between the particulate and dissolved $\mathrm{OM}$ pools was greatest when fresh, reactive $\mathrm{OM}$ is hydrolyzed under less oxygenated conditions in the lower St. Lawrence estuary. Hydrolysis of less reactive OM under aerobic conditions in the gulf of St. Lawrence appears to be less specific with regards to $\mathrm{C}$ - and $\mathrm{N}$-containing components. The general validity of these results need to be further tested in other environments, and we cannot be certain whether the $\mathrm{C} / \mathrm{N}$ fractionation between POM and DOM is mostly due to the hydrolysis step of the OM degradation or whether it is partly the result of the elemental fractionation during subsequent DOM mineralization and/or the selective adsorption of DOM to mineral phases. Nonetheless, our results have implications for the interpretation of bulk $\mathrm{OM} \mathrm{C} / \mathrm{N}$ ratios in sedimentary archives, as they confirm that variable preservation conditions and sedimentation regimes can result in variable early diagenetic $\mathrm{C} / \mathrm{N}$ shifts that can 
compromise the use of $\mathrm{C} / \mathrm{N}$ ratios of sedimentary $\mathrm{OM}$ as basic $\mathrm{OM}$ source indicator.

Both in the lower estuary and in the gulf, DON contributes significantly to the overall dissolved $\mathrm{N}$ exchange between the sediments and the water column. Assuming that DOM fluxes determined for the St. Lawrence estuarine environment are representative of coastal shelf environments in general, extrapolation of our results reveals that DON fluxes from continental shelf represent an important component of the global $\mathrm{N}$ cycle. The fate and reactivity of the DON escaping the sediments is uncertain. Several studies have reported on the dynamic nature of DON in the ocean water column and the susceptibility of DON to bacterial enzymatic remineralization (e.g., Bastviken et al., 2004; Van Engeland et al., 2010). Given the discrepancy between relatively large marine benthic DON fluxes (this study) and the low DON concentrations in the ocean (e.g., Knapp et al., 2005; Bourbonnais et al., 2009), it is likely that sediment-derived DON undergoes rapid oxidation and adds substantially to the reactive water column DIN pool (Bastviken et al., 2004; e.g. Burdige, 2007; Van Engeland et al., 2010). Benthic DON fluxes therefore represent an important component of the internal $\mathrm{N}$ cycle, eventually supporting a significant fraction of ecosystem productivity.

Acknowledgements. We thank the captain and crew of the RV Coriolis II. We are also grateful to P. Cayer at UQAM and M. Birkicht from the ZMT-Bremen University for their valuable suggestions regarding the analysis of DOC. M. Alkhatib acknowledges financial support through a Geotop Research Centre scholarship. Funds to support the cruise and research were obtained through grants from NSERC Canada. Comments and suggestions by D. Burdige and two anonymous reviewers helped to improve the quality of this paper.

Edited by: S. Bouillon

\section{References}

Alkhatib, M., Schubert, C. J., del Giorgio, P. A., Gelinas, Y., and Lehmann, M. F.: Organic matter reactivity indicators in sediments of the St. Lawrence estuary, Est. Coast. Shelf Sci., 102, 36-47, 2012a.

Alkhatib, M., Lehmann, M. F., and del Giorgio, P. A.: The nitrogen isotope effect of benthic remineralization-nitrificationdenitrification coupling in an estuarine environment, Biogeosciences, 9, 1633-1646, doi:10.5194/bg-9-1633-2012, 2012 b.

Alperin, M. J., Martens, C. S., Albert, D. B., Suayah, I. B., Benninger, L. K., Blair, N. E., and Jahnke, R. A.: Benthic fluxes and porewater concentration profiles of dissolved organic carbon in sediments from the North Carolina continental slope, Geochim. Cosmochim. Ac., 63, 427-448, 1999.

Arnarson, T. S. and Keil, R. G.: Mechanisms of pore water organic matter adsorption to montmorillonite, Mar. Chem., 71, 309-320, 2000.
Bastviken, D., Persson, L., Odham, G., and Tranvik, L.: Degradation of dissolved organic matter in oxic and anoxic lake water, Limnol. Oceanogr., 49, 109-116, 2004.

Bender, M., Martin, W., Hess, J., Sayles, F., Ball, L., and Lambert, C.: A whole - core squeezer for interfacial pore - water sampling, Limnol. Oceanogr., 32, 1214-1225, 1987.

Benner, R.: Chemical composition and reactivity, in Biogeochemistry of marine dissolved organic matter, edited by: D. A. Hansell and Carlson, C. A., Academic Press, 59-90, 2002.

Berman, T. and Bronk, A.: Dissolved organic nitrogen: a dynamic participant in aquatic ecosystems, Aquat. Microb. Ecol., 31, 279305, 2003.

Berner, R. A.: A Theoretical Approach, Early Diagenesis Princeton University Press, Princeton, New Jersey, 1980.

Blackburn, T. H., Hall, P. O. J., Hulth, S., and Landén, A.: Organic$\mathrm{N}$ loss by efflux and burial associated with a low efflux of inorganic $\mathrm{N}$ and with nitrate assimilation in Arctic sediments (Svalbard, Norway), Mar. Ecol. Prog. Ser., 141, 283-293, 1996.

Boetius, A. and Lochte, K.: Regulation of microbial enzymatic degradation of organic matter in deep sea sediments, Mar. Ecol. Prog. Ser., 104, 299-307, 1994.

Bolliger, R., Brand, H., Hiihener, P., Hanselmann, K. W., and Bachofen, R.: Squeeze - water analysis for the determination of microbial metabolites in lake sediments - Comparison of methods, Limnol. Oceanogr., 37, 448-455, 1992.

Boto, K. G., Alongi, D. M., and Nott, A. L. J.: Dissolved organic carbon-bacteria interactions at sediment-water interface in a tropical mangrove system, Mar. Ecol. Prog. Ser., 51, 243-251, 1989.

Boudreau, B. P.: (ED.) Diagenetic models and their implementation: modelling transport and reaction in aquatic sediments, Springer, Berlin, Heidelberg, New York, 1996.

Bourbonnais, A., Lehmann, M. F., Waniek, J. J., and Schulz-Bull, D. E.: Nitrate isotope anomalies reflect $\mathrm{N}_{2}$ fixation in the Azores Front region (subtropical NE Atlantic), J. Geophys. Res., 114, C03003, doi:10.1029/2007JC004617, 2009.

Bourgault, D., Cyr, F., Galbraith, P. S., and Pelletier E.: Relative importance of pelagic and sediment respiration in causing hypoxia in a deep estuary, J. Geophys. Res., 117, C08033, doi:10.1029/2012JC007902, 2012.

Bourgoin, L. H. and Tremblay, L.: Bacterial reworking of terrigenous and marine organic matter in estuarine water columns and sediments, Geochim. Cosmochim. Acta, 74, 5593-5609. 2010.

Braman, R. S. and Hendrix, S. A.: Nanogram nitrite and nitrate determination in environmental and biological materials by V(III) reduction with chemiluminescence detection, Anal. Chem., 61, 2715-2718, 1989.

Bronk, D. A. and Steinberg, D. K.: Nitrogen Regeneration, in: Nitrogen in the Marine Environment. edited by: Capone, D. G., Bronk, D. A., Mulholland, M., and Carpenter, E., Elsevier Press., Amsterdam, 385-468, 2008.

Bronk, D. A., Lomas, M., Glibert, P. M., Schukert, K. J., and Sanderson, M. P.: Total dissolved nitrogen analysis: comparisons between the persulfate, UV and high temperature oxidation method, Mar. Chem., 69, 163-178, 2000.

Brunnegård, J., Grandel, S., Ståhl, H., Tengberg, A., and Hall, P. O. J.: Nitrogen cycling in deep-sea sediments of the Porcupine Abyssal Plain, NE Atlantic, Prog. Oceanogr., 63, 159-181, 2004. 
Burdige, D. J.: Dissolved organic matter in Chesapeake Bay sediment pore waters, Org. Geochem., 32, 487-505, 2001.

Burdige, D. J.: Preservation of organic matter in marine sediments: controls, mechanisms, and an imbalance in sediment organic carbon budgets?, Chem. Rev., 107, 467-485, 2007.

Burdige, D. J. and Homestead, J.: Fluxes of dissolved organic carbon from Chesapeake Bay sediments, Geochim. Cosmochim. Acta, 58, 3407-3424, 1994.

Burdige, D. J. and Zheng, S.: The biogeochemical cycling of dissolved organic nitrogen in estuarine sediments, Limnol. Oceanogr., 43, 1796-1813, 1998.

Burdige, D. J., Alperin, M. J., Homstead, J., and Martins, C. S.: The role of benthic fluxes of dissolved organic carbon in oceanic and sedimentary carbon cycling, Geophys. Res. Lett., 19, 1851$1854,1992$.

Codispoti, L. A., Brandes, J. A., Christensen, J. P., Devol, A. H., Naqvi, S. W. A., Paerl, H. W., and Yoshinari, T.: The oceanic fixed nitrogen and nitrous oxide budgets: Moving targets as we enter the anthropocene?, Sci. Mar., 65, 85-105, 2001.

Colombo, J. C., Silverberg, N., and Gearing, J. N.: Biogeochemistry of organic matter in the Laurentian Trough, II. Bulk composition of the sediments and relative reactivity of major components during early diagenesis, Mar. Chem., 51, 295-314, 1996.

Dauwe, B., Middelburg, J. J., Herman, P., and Heip, C.: Linking diagenetic alteration of amino acids and bulk organic matter reactivity, Limnol. Oceanogr., 44, 1809-1814, 1999.

Emerson, S. and Hedges, J. I.: Processes controlling the organic carbon content of open ocean sediments. Paleoceanogr., 3, 621634, 1988.

Emerson, S. and Hedges, J. I.: Sediment diagenesis and benthic flux, in: Treatise on Geochemistry, edited by: Elderfield, H., Elsevier, New York, 293-319, 2003.

Enoksson, V.: Nutrient recycling by coastal sediments: effects of added algal material, Mar. Ecol. Prog. Ser., 92, 245-254, 1993.

Faganeli, J., Pezdic, J., Ogorelec, B., Herndl, G. J., and Dolenec, T.: The role of sedimentary biogeochemistry in the formation of hypoxia in shallow coastal waters (Gulf of Trieste, northern Adriatic), in: Modern and Ancient Continental Shelf Anoxia, edited by: Tyson, R. V. and Pearson, T. H., The Geological Society, London, 58, 107-117, 1991.

Fenchel, T., King, G. M., and Blackburn, T. H.: Bacterial Biogeochemistry, The Ecophysiology of Mineral Cycling, Academic Press, San Diego, 1998.

Gilbert, D., Sundby, B., Gobeil, C., Mucci, A., and Tremblay, G. H.: A seventy-two-year record of diminishing deep-water oxygen in the St. Lawrence estuary: The northwest Atlantic connection, Limnol. Oceanogr., 50, 1654-1666, 2005.

Hansen, H. P. and Koroleff, F.: Determination of nutrients, in: Methods of seawater analysis, 3.Ed., edited by: Grasshoff, K., Kremling, K., and Erhardt, M., Wiley VCH, Weinheim, 159-228, 1999.

Hansen, L. S. and Blackburn, T. H.: Aerobic and anaerobic mineralization of organic material in marine sediment microcosms, Mar. Ecol. Prog. Ser., 75, 283-291, 1991.

Hall, O. J., Brunnegard, J., Hulthe, G., Martin, W. R., Stahl, H., and Tengberg, A.: Dissolved organic matter in abyssal sediments, Limnol. Oceanogr., 52, 19-3, 2007.
Hartnett, H. E., Keil, R. G., Hedges, J. I., and Devol, A. H.: Influence of oxygen exposure time on organic carbon preservation in continental margin sediments, Nature, 391, 572-574, 1998.

Hedges, J. I., Hu, F. S., Devol, A. H., Hartnett, H. E., Tsamakis, E., and Keil, R. G.: Sedimentary organic matter preservation: a test for selective degradation under oxic conditions, Am. J. Sci., 299, 529-555, 1999.

Holcombe, B. L., Keil, R. G., and Devol, A. H.: Determination of porewater dissolved organic carbon fluxes from Mexican margin sediments, Limnol. Oceanogr., 46, 298-308, 2001.

Jahnke, R. A.: A simple, reliable, and inexpensive porewater sampler, Limnol. Oceanogr., 33, 483-487, 1988.

Knapp, A., Sigman, D., and Lipschultz, F.: N isotope composition of dissolved organic nitrogen and nitrate at the Bermuda Atlantic time-series study site, Global Biogeochem. Cy., 19, GB1018, doi:10.1029/2004GB002320, 2005.

Kristensen, E. and Holmer, M.: Decomposition of plant materials in marine sediment exposed to different electron acceptors $\left(\mathrm{O}_{2}\right.$, $\mathrm{NO}_{3}^{-}$, and $\mathrm{SO}_{4}^{-2}$ ), with emphasis on substrate origin, degradation kinetics, and the role of bioturbation, Geochim. Cosmochim. Ac., 65, 419-433, 2001.

Lahajnar, N., Rixen, T., Gaye-Haakea, B., Schäfer, P., and Ittekkot, V.: Dissolved organic carbon (DOC) fluxes of deep-sea sediments from the Arabian Sea and NE Atlantic, Deep-Sea Res. Pt. II, 52, 1947-1964, 2005.

Lalonde, K., Mucci, A., and Gélinas, Y.: Preservation of organic matter promoted by iron, Nature, 483, 198-200, 2012.

Lehmann, M. F., Barnett, B., Gélinas, Y., Gilbert, D., Maranger, R. J., Mucci, A., Sundby, B., and Thibodeau, B.: Aerobic respiration and hypoxia in the Lower St. Lawrence estuary: Stable isotope ratios of dissolved oxygen constrain oxygen sink partitioning, Limnol. Oceanogr., 54, 2157-2169, 2009.

Lomstein, B. A., Jensen, A. G. U., Hansen, J. W., Andreasen, J. B, Hansen, L. S., Berntsen, J., and Kunzendorf, H.: Budgets of sediment nitrogen and carbon cycling in the shallow water of Knebel Vig, Denmark, Aquat. Microb. Ecol., 14, 69-80, 1998.

Lønborg, K., Davidson, K., Álvarez-Salgado, X. A., and Miller, A. E. J.: Bioavailability and bacterial degradation rates of dissolved organic matter in a temperate coastal area during an annual cycle, Mar. Chem., 113, 219-226, 2009.

Louchouarn, P., Lucotte, M., Camel, R., Gagne, J. P., and Richard, L. F.: Sources and early diagenesis of lignin and bulk organic matter in sediments of the Lower St. Lawrence estuary and the Saguenay Fjord, Mar. Chem., 58, 3-26, 1997.

Maher, D. T. and Eyre, B. D.: Benthic fluxes of dissolved organic carbon in three temperate Australian estuaries: Implications for global estimates of benthic DOC fluxes, J. Geophys. Res., 115, G04039, doi:10.1029/2010JG001433, 2010

Martin, W. R. and McCorkle, D. C.: Dissolved organic carbon concentrations in marine pore water determined by high temperature oxidation, Limnol. Oceanogr., 38, 1464-1479, 1993.

Meyers, P. A. and Eadie, B. J.: Sources, degradation and recycling of organic matter associated with sinking particles in Lake Michigan, Org. Geochem., 20, 47-56, 1993.

Milliman, J. D.: Production and accumulation of calcium carbonate in the ocean: Budget of a nonsteady state, Global Biogeochem. Cy., 7, 927-957, doi:10.1029/93GB02524, 1993

Muzuka, A. N. N. and Hillaire-Marcel, C.: Burial rates of organic matter along the eastern Canadian margin and stable isotope con- 
straints on its origin and diagenetic evolution, Mar. Geol., 160, 251-270, 1999.

Otto, S. and Balzer, W.: Release of dissolved organic carbon (DOC) from sediments of the N.W. European Continental Margin (Goban Spur) and its significance for benthic carbon cycling, Prog. Oceanogr., 42, 127-144, 1998.

Schubert, C. J., Niggemann, J., Klockgether, G., and Ferdelman, T. G.: Chlorin Index: A new parameter for organic matter freshness in sediments, Geochem. Geophys. Geosyst., 6, Q03005, doi:10.1029/2004GC000837, 2005.

Seeberg-Elverfeldt, J., Schlüter, M., Feseker, T., and Kölling, M.: Rhizon sampling of pore waters near the sediment/water interface of aquatic systems, Limnol. Oceanogr. Meth., 3, 361-371, 2005.

Seitzinger, S. P. and Sanders, R. W.: Atmospheric inputs of dissolved organic nitrogen stimulate estuarine bacteria and phytoplankton, Limnol. Oceanogr., 44, 721-730, 1999.

Seitzinger, S. P., Sanders, R. W., and Styles, R.: Bioavailability of DON from natural and anthropogenic sources to estuarine plankton, Limnol. Oceanogr., 47, 353-366, 2002.

Silverberg, N., Bakker, J., Hedenborn, H., and Sundby, B.: Oxygen profiles and organic carbon fluxes in Laurentian Trough sediments, Neth. J. Sea Res., 21, 95-105, 1987.

Silverberg, N., Sundby, B., Mucci, A., Zhong, S., Arakaki, T., Hall, P., Landen, A., and Tengberg, A.: Remineralization of organic carbon in eastern Canadian continental margin sediments, DeepSea Res. Pt. II, 47, 699-731, 2000.

Skoog, A. and Arias-Esquivel, V. A.: The effect of anoxia and reoxygenation on benthic fluxes of organic carbon, phosphate, iron, and manganese, Sci. Tot. Environ., 407, 6085-6092, 2009.

Skoog, A., Hall, P. O. J., Hulth, S., Paxéus, N., Rutgers van der Loeff, M. M., and Westerlund, S.: Early diagenetic production and sediment - water exchange of fluorescent dissolved organic matter in the coastal environment, Geochim. Cosmochim. Ac., 60, 3619-3629, 1996.
Sloth, N. P., Blackburn, H., Hansen, L. S., Risgaard-Petersen, N., Lomstein, B. A.: Nitrogen cycling in sediments with different organic loading, Mar. Ecol. Prog. Ser., 116, 163-170, 1995.

Thibodeau, B., de Vernal, A., and Mucci, A.: Recent eutrophication and consequent hypoxia in the bottom waters of the Lower St. Lawrence estuary: micropaleontological and geochemical evidence, Mar. Geol., 231, 37-50, 2006.

Thibodeau, B., Lehmann, M. F., Kowarzyk, J., Mucci, A., Gélinas, Y., Gilbert, D., Maranger, R., and Alkhatib, M.: Benthic nutrient fluxes along the Laurentian Channel: Environmental controls and impact on the $\mathrm{N}$ - budget of the St. Lawrence marine system, Estuar. Coast. Shelf Sci., 90, 195-205, 2010.

Tremblay, L. and Benner, R.: Microbial contributions to N - immobilization and organic matter preservation in decaying plant detritus, Geochim. Cosmochim. Ac., 70, 133-146, 2006.

Van Engeland, T., Soetaert, K., Knuijt, A., Laane, R. W. P. M., and Middelburg, J. J.: Dissolved organic nitrogen dynamics in the North Sea: A time series analysis (1995-2005), Estuar. Coast. Shelf Sci., 89, 31-42, 2010.

van der Zee, C., Roberts, D. R., Rancourt, D. G., and Slomp, C. P.: Nano-goethite is the dominant reactive oxyhydroxide phase in lake and marine sediments, Geol., 31, 993-996, 2003.

Weston, N. B., Porubsky, W. P., Samarkin, V. A., Erickson, M., Macavoy, S. E., and Joye, S. B.: Porewater stoichiometry of terminal metabolic products, sulfate, and dissolved organic carbon and nitrogen in estuarine intertidal Creek-bank sediments, Biogeochem., 77, 375-408, 2006.

Wilczek, S., Fischer, H., and Pusch, M. T.: Regulation and seasonal dynamics of extracellular enzyme activities in the sediments of a large lowland river, Microb. Ecol., 50, 253-267, doi:10.1007/s00248-004-0119-2, 2005. 